\title{
Multidimensional Pain Evaluation Scale
}

\author{
Fátima Aparecida Emm Faleiros Sousa ${ }^{1}$ \\ Lilian Varanda Pereira ${ }^{2}$ \\ Roberta Cardoso ${ }^{3}$ \\ Priscilla Hortense ${ }^{4}$
}

This study developed a pain evaluation scale and validated it for the Portuguese language. Development of the inventory - 308 readily available pain descriptors - were searched in international literature and validated by six judges. One hundred descriptors of acute pain and 100 descriptors of chronic pain were found, which were used in the next stage. Statistical validation - 493 health professionals and 146 patients experiencing acute and chronic pain participated in the study. Instructions, pain descriptors and respective definitions, pen and measuring tape were provided to participants. Psychophysical methods were used to establish categories, magnitude and cross-modality matching using line-length. Results revealed the ranking of the most frequently used descriptors of acute and chronic pain, with power equal to 0.99 , close to the predicted (one), using line-length estimations. The Multidimensional Pain Evaluation Scale is thus validated for the Portuguese language.

Descriptors: Subject Headings; Pain; Pain Measurement.

\footnotetext{
${ }^{1}$ RN, Full Professor, Escola de Enfermagem de Ribeirão Preto, Universidade de São Paulo, WHO Collaborating Centre for Nursing Research Development, Brazil, e-mail: faleiros@eerp.usp.br.

${ }^{2}$ Faculty, Faculdade de Enfermagem, Universidade Federal de Goiás, Brazil, e-mail: Ivaranda@terra.com.br.

${ }^{3}$ Adjunct Professor I, Universidade Federal de São Carlos, Brazil, e-mail: prihrt@yahoo.com.br.

${ }^{4}$ Post-doctoral fellow, Lawrence S. Bloomberg Faculty of Nursing, University of Toronto, Canada, e-mail: rps.cardoso@utoronto.ca.
}

Corresponding Author:

Priscilla Hortense

Universidade Federal de São Carlos, Departamento de Enfermagem

Rodovia Washington Luis, km 235 Caixa Postal 676

CEP: 13565-905 São Carlos, SP, Brazil

E-mail: rps.cardoso@utoronto.ca. 


\section{Escala Multidimensional de Avaliação de Dor (EMADOR)}

Os objetivos deste estudo foram elaborar escala de avaliação de dor e validá-la para a língua portuguesa. Elaboração de inventário - foram pesquisados 308 descritores de dor da literatura mundial e, a partir desses, seis juízes realizaram a validação aparente e de conteúdo. Como resultados foram encontrados 100 descritores de dor aguda e 100 de crônica, os quais foram utilizados na próxima etapa. Validação estatística - participaram 493 profissionais da saúde e 146 portadores de dor aguda e de crônica. Usou-se, como material, instruções aos participantes, descritores de dor e suas definições, caneta e trena. Foram utilizados métodos psicofísicos: estimação de categorias, estimação de magnitudes e emparelhamento intermodal com modalidade em comprimento de linhas. Os resultados mostram escalonamento dos descritores de maior caracterização para a dor aguda e para a dor crônica, tendo sido encontrado expoente igual a 0,99, próximo ao predito (um) ao utilizar comprimentos de linhas e estimativas numéricas. Foi validada para a língua portuguesa a Escala Multidimensional de Avaliação de Dor (EMADOR).

Descritores: Descritores; Dor; Medição da Dor.

\section{Escala Multidimensional de Evaluación del Dolor (EMEDOR)}

Los objetivos de este estudio fueron elaborar una escala de evaluación del dolor y validarla para la lengua portuguesa. Elaboración de inventario - fueron investigados 308 descriptores del dolor en la literatura mundial y, a partir de estos, seis jueces realizaron la validación aparente y de contenido. Como resultados fueron encontrados 100 descriptores del dolor agudo y 100 del crónico, los cuales fueron utilizados en la próxima etapa. Validación estadística - participaron 493 profesionales de la salud y 146 portadores de dolor agudo y de crónico. Se usó, como material, instrucciones a los participantes, descriptores de dolor y sus definiciones, lápiz y cinta de medir. Fueron utilizados métodos psicofísicos: estimación de categorías, estimación de magnitudes y emparejamiento intermodal con modalidad en largo de líneas. Los resultados muestran escalonamiento de los descriptores de mayor caracterización para el dolor agudo y para el dolor crónico, fue encontrado exponente igual a 0,99, próximo al predicho (uno) al utilizar el largo de líneas y estimativas numéricas. Fue validado para la lengua portuguesa la Escala Multidimensional de Evaluación del Dolor (EMEDOR).

Descriptores: Descriptores; Dolor; Dimensión del Dolor.

\section{Introduction}

Subjective concepts and phenomena such as pain are difficult to accurately measure, that is, to quantify through instruments and processes that are free of systematic errors, which is a common issue in Social, Health and Human Sciences. It is impossible to manipulate a problem of this nature without a measure on which to base the treatment or therapeutic practice, with difficulty determining whether a treatment is necessary, efficient or even when it must be interrupted.

However, through appropriate measurement one can determine whether the risks of a given treatment are worse that the harm caused by the clinical problem and choose the best and safest treatment among those available. Appropriate measurement also permits examining the nature, origins and clinical reports of pain related to clients' emotional, motivational and cognitive characteristics and personality.

To understand the phenomenon of pain and evaluate the efficacy of interventions, more sophisticated measures are needed to determine not only the intensity 
of pain, but also to evaluate motivational, cognitive and affective responses to pain. In addition, methods to quantify the subjective experience with scientific rigor and reproducibility are needed as well as follow-up and analysis of the mechanisms of action of different drugs and therapies, monitoring changes in the quality and/ or dimensions of pain, permitting the client him/herself to opt to report, describe and evaluate his/her own perception of pain ${ }^{(1-2)}$.

Pain can be misinterpreted and underestimated if not appropriately evaluated, which can lead to inadequate manipulation and consequently harm clients' quality of life. Pain is influenced by cultural and situational factors as well as by the care received, motivation, emotion and other psychological variables in addition to external ones. Evaluations of pain are mostly based on what clients report complemented by clinical examination. The client is considered (in a clinical or research setting) a measurement tool.

Psychophysics' main assumption is that the perceptual system is a measurement instrument that generates results (experiences, judgments, responses) that can be systematically measured and analyzed. Hence, it is worth mentioning the importance of attentively listening to another person with empathy, interest, respecting differences and uniqueness so that the researcher does not project his/her own values and beliefs and inner world and thereby distort his/her perception in relation to the other's perception of life and pain.

The psychophysical methodology and procedures developed in sensorial psychophysics, currently used in Sciences, are promising in ranking subjective phenomena. They are an active system capable of grasping the diversity and multidimensionality of the human being and the beauty of the human mind and brain through descriptors ${ }^{(3-6)}$.

\section{Objectives}

To develop a Multidimensional Pain Evaluation Scale in the Portuguese language. To subjectively and statistically validate the Multidimensional Pain Evaluation Scale.

\section{Method}

\section{Inventory's development}

Participants: six professionals, faculty members of federal and state universities also working in medium and large general hospitals: two physicians, two nurses, one psychologist and one physiotherapist were invited to be judges in the face and content validation process of the developed instrument.

Material: a list of descriptors contained in the McGill Pain Questionnaire(7), books, scientific articles from the international literature in the field, a Portuguese dictionary $^{(8)}$, a medical dictionary ${ }^{(9)}$, an English/ Portuguese dictionary ${ }^{(10)}$, and paper and pen were used to develop this instrument. A paper pad with specific instructions for the participants and a list of 308 pain descriptors with their respective definitions and pen were used for the face and content validations.

Procedure: the descriptors that compose the instrument were selected as following:

- descriptors extracted from international and national scientific literature were translated to Portuguese by a English teacher who has lived in the United States for four years and from Portuguese to English by a Portuguese teacher living in Brazil;

- identification of descriptors based on the authors' professional experience with patients experiencing acute and chronic pain;

- searching for words that could be used to describe pain in a Portuguese dictionary ${ }^{(8)}$ and a medical dictionary ${ }^{(9)}$.

The instrument contained a list of 308 descriptors and their respective definitions developed according to Portuguese and medical dictionaries. A 7-item scale was added to each definition with alternatives that varied from 0 to 6 , to which participants should match their judgments and attribute scores that would represent, according to their perceptions, the extent to which such descriptor characterized their pain.

Data analysis: for each of the 308 identified descriptors an average and standard deviation of this average was computed. The 100 descriptors that represented the highest average were selected to compose the inventory. Among the descriptors with equal averages, those with the smallest standard deviation were chosen.

The final inventory contained 100 descriptors for acute pain and 100 for chronic pain.

\section{Statistical validation}

Participants: 493 health professionals (physicians, nurses and psychologists) and 146 participants with acute and chronic pain participated in the study. All participants signed free and informed consent forms approved by the Research Ethics Committee at the Hospital das Clínicas at the University of São Paulo at 
Ribeirão Preto, Medical School (Processes HCRP $n^{\circ}$ 7481/98 e HCRP no 11696/2004).

Material: paper pad containing specific instructions for each used method and respective tasks for participants followed by pain descriptors and respective definitions, pen and measuring tape.

Study setting: Hospital das Clínicas at the University of São Paulo at Ribeirão Preto, Medical School.

Procedure: direct and indirect psychophysical methods, estimation of categories, estimation of magnitudes and cross-modality matching of answers regarding line-length. Method to rank categories (participants' task: to chose a number in a 7-item scale for each descriptor that better characterized the studied pain - acute or chronic); method to estimate the magnitude of pain (participants' task: to choose a number for the pain descriptor, which proportionally corresponded to the intensity of the studied pain - acute or chronic - in relation to the standard stimulus, whose numerical value was 100 for a given descriptor); crossmodality matching method - line-length (participants' task: to designate a line-length proportional to the level of attribution of the descriptor to acute or chronic pain - in relation to the standard stimulus, whose visual value was $50 \mathrm{~cm}$ for a given descriptor). Such procedures were used both with professionals and patients. Professionals were asked to judge the descriptor according to their professional experience related to the perception of acute or chronic pain in others, while patients were asked to judge the descriptor according to their own perceived pain.

Data analysis: the geometric average, standard deviation and position order of estimates attributed to each descriptor of acute pain and chronic pain were computed. The geometric average of the estimates of acute and chronic pain were graphically depicted in logarithmic scale as a function of the geometric averages of the line-length paired to each descriptor, and a regression line was fitted to the data through the least squares method. Then, the power was calculated and compared to the predicted power ${ }^{(6)}$.

\section{Results}

The results presented in Table 1 show the 40 descriptors that most characterize acute pain and the 40 descriptors that most characterize chronic pain.

Table 1 - Geometric Average (GA) and geometric standard deviation (GSD) and positions order (PO) of the estimation of magnitude attributed to the 40 descriptors that most characterize acute pain and the 40 descriptors the most characterize chronic pain ${ }^{(11-12)}$.

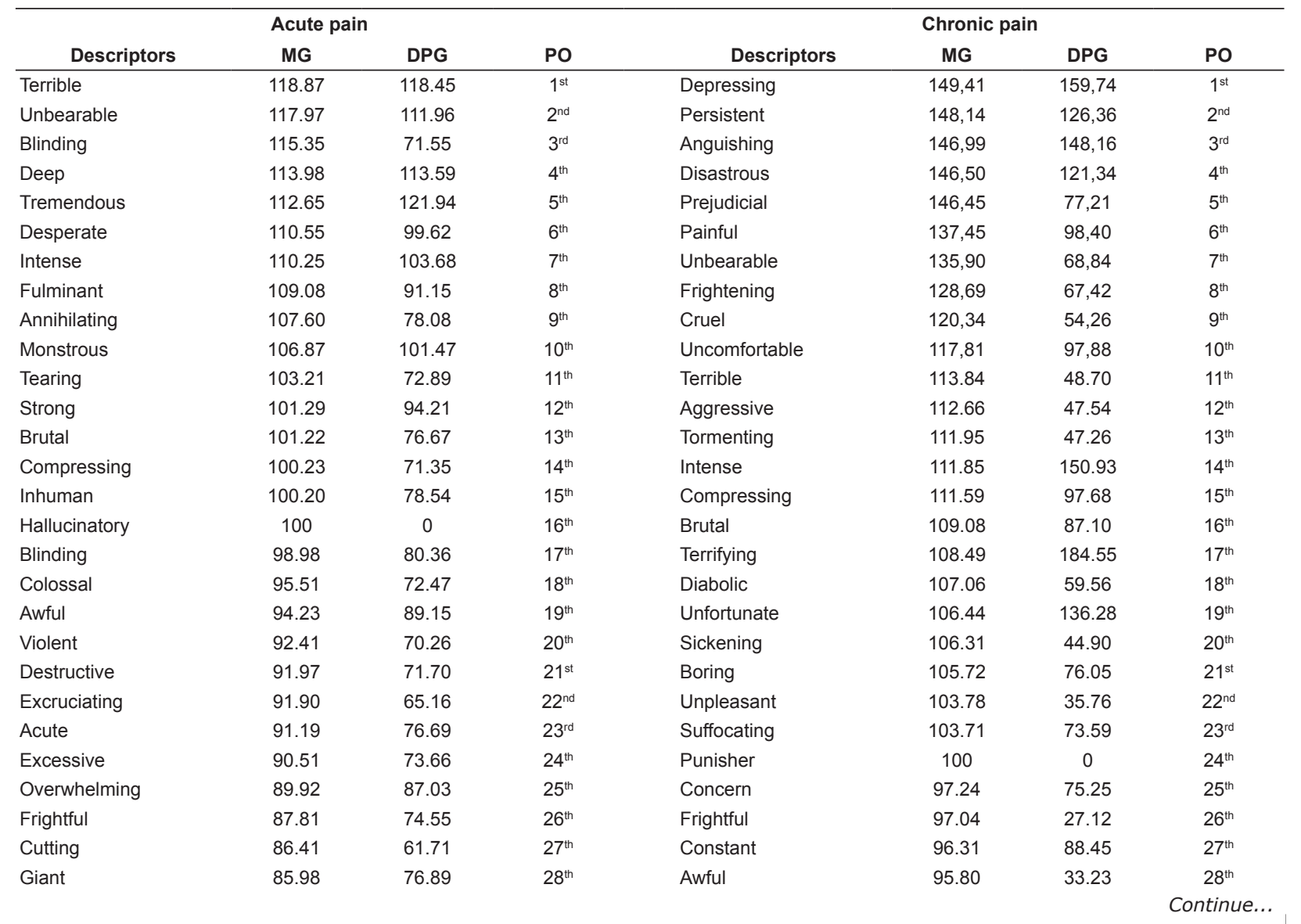


Table 1 - Continuation

\begin{tabular}{|c|c|c|c|c|c|c|c|}
\hline \multicolumn{4}{|c|}{ Acute pain } & \multicolumn{4}{|c|}{ Chronic pain } \\
\hline Descriptors & MG & DPG & PO & Descriptors & MG & DPG & PO \\
\hline Terrifying & 84.98 & 58.95 & $29^{\text {th }}$ & Demonic & 95.35 & 67.47 & $29^{\text {th }}$ \\
\hline Anguishing & 84.87 & 59.08 & $30^{\text {th }}$ & Spreading & 94.36 & 135.09 & $30^{\text {th }}$ \\
\hline Distressing & 83.13 & 48.75 & $31^{\text {st }}$ & Ravager & 93.74 & 85.74 & $31^{\text {st }}$ \\
\hline Penetrating & 80.98 & 60.83 & $32^{\text {nd }}$ & Continuous & 92.97 & 15.09 & $32^{\text {nd }}$ \\
\hline Smarting & 76.52 & 60.20 & $33^{\text {rd }}$ & Excessive & 92.33 & 54.77 & $33^{\text {rd }}$ \\
\hline Burning & 76.02 & 71.42 & $34^{\text {th }}$ & Miserable & 89.20 & 63.40 & $34^{\text {th }}$ \\
\hline Aggressive & 75.83 & 54.17 & $35^{\text {th }}$ & Exaggerated & 88.61 & 41.53 & $35^{\text {th }}$ \\
\hline Suffocating & 75.19 & 102.12 & $36^{\text {th }}$ & Damn & 87.91 & 16.66 & $36^{\text {th }}$ \\
\hline Paralyzing & 74.73 & 61.08 & $37^{\text {th }}$ & Disturbing & 87.82 & 15.23 & $37^{\text {th }}$ \\
\hline Unbridled & 74.72 & 53.62 & $38^{\text {th }}$ & Hateful & 87.65 & 63.92 & $38^{\text {th }}$ \\
\hline Importunate & 74.60 & 68.65 & $39^{\text {th }}$ & Exhausting & 87.63 & 63.96 & $39^{\text {th }}$ \\
\hline Stabbing & 74.31 & 55.38 & $40^{\text {th }}$ & Harmful & 87.10 & 42.69 & $40^{\text {th }}$ \\
\hline
\end{tabular}

Results show that the most frequently used descriptors to characterize acute pain were: terrible, unbearable, blinding, deep, tremendous, desperate, intense, fulminant, annihilating and monstrous. The most frequently used descriptors to characterize chronic pain were: depressing, persistent, anguishing, disastrous, prejudicial, painful, unbearable, frightening, cruel and uncomfortable.

A line was fitted to data by the least square method and graphically depicted, $n=1.12 ; r^{2}=0.98$ (Figure 1 ).

Considering that the participants tend to restrict the range of their adjustments according to the variable they control, inverted coordinates were used in the figure, that is, length of lines as a function of corresponding estimates, for each descriptor. The result was a straight line with $n=0.87 ; r^{2}=0.98$. In order to mediate the regression effect, the geometric average of the powers of the length of lines versus an estimate of magnitude and an estimate of magnitude versus lengths of lines(13) was computed and 0.99 was the resulting value.

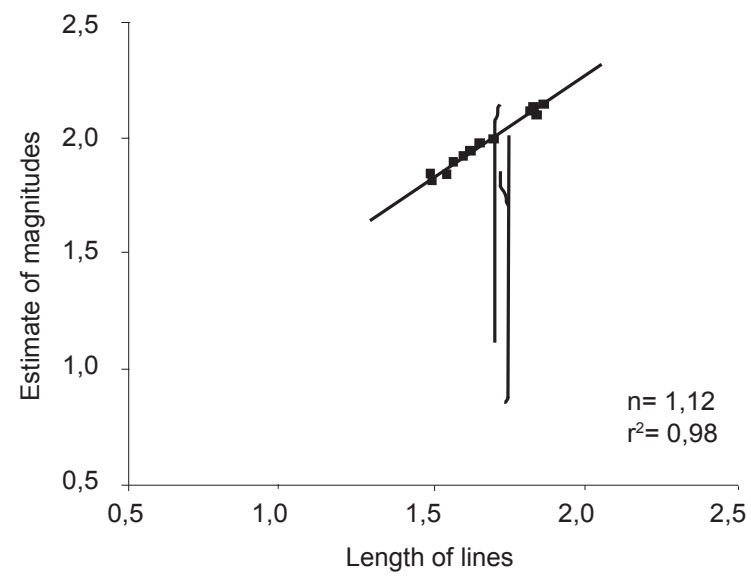

Figure 1 - Logarithms of geometric averages of estimates of magnitudes and the logarithms of geometric averages of pairing of length of lines attributed to descriptors of acute pain
In relation to the descriptors of chronic pain, the geometric averages of the estimates of magnitudes were graphically depicted in a logarithmic scale as a function of the corresponding geometric averages of estimates of the pairing of length of lines to each descriptor of chronic pain (Figure 2 ). A line was fitted by the least square method, $n=1.12 ; r^{2}=0,98$.

The estimates of the pairing to length of lines were depicted as a function of the corresponding estimates of magnitudes for each descriptor, which resulted in a line with $n=0.87 ; r^{2}=0.98$.

Taking the geometric average of the two slopes is adequate to mediate the regression effect; 0.99 was the value found.

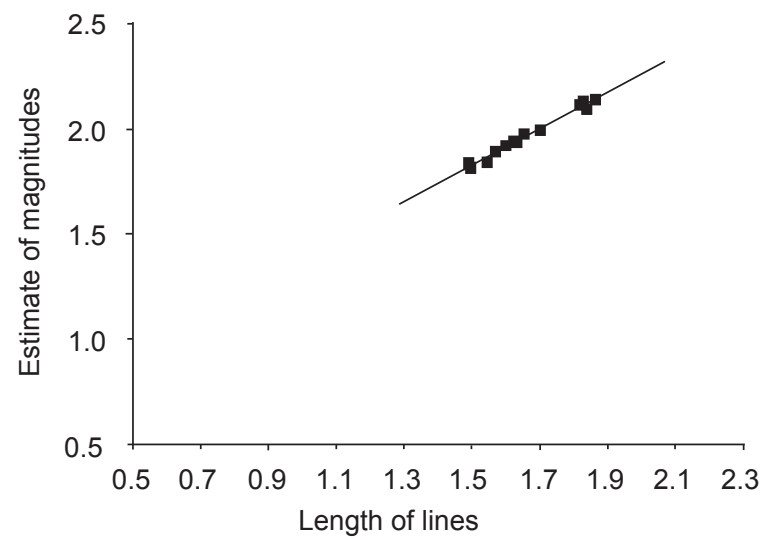

Figure 2 - Logarithms of geometric averages of magnitudes and logarithms of geometric average of the pairing of length of lines attributed to descriptors of chronic pain

Hence, the psychophysical scale to associate descriptors of acute and chronic pains is validated for Portuguese.

The multidimensional Pain Evaluation Scale is validated for Portuguese and is presented in Figures 3 and 4. 


\section{MULTIDIMENSIONAL PAIN EVALUATION SCALE (MPES) \\ (Faleiros Sousa et. al.)}

\section{Instructions}

1- The professional will ask the client to judge the intensity of pain using values from 0 to 10 in the scale below in which 0 indicates "no pain", 10 "highest pain" and the other scores, from 2 to 9 , should be used to indicate intermediate levels of pain. Afterwards, check on the graphic the value attributed according to the hour.

2- The client should check one or more descriptors that characterize the perceived pain. Afterwards, the professional should check on the graphic with an " $x$ " the chosen descriptor(s) according to the hour. This lacuna should be filled out after the perceived pain is characterized as acute or chronic according to descriptors and their respective definitions.

3-The professional will ask the client to indicate the site of perceived pain. After visualizing the figure in this instrument, the professional should locate the pertinent area(s) and record it (them) on the graph according to the corresponding number(s) of the human body, followed by the hour of the perceived pain(s).

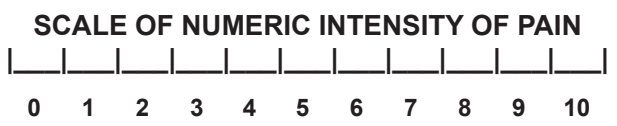

Check whether the perceived pain is chronic and acute

\section{() Acute pain}

\section{1) Terrible}

1. Incite or causes terror; terrifying.

2.extraordinary; strange.

3.Very big; huge.

4.very bad.

2) Unbearable

1. Not tolerable; intolerable.

2.uncomfortable.

\section{3) Blinding}

1.Drives one mad, crazy; makes one to lose one's mind.

\section{4) Deep}

1.extense, considered from the entrance up to the opposite extreme.

Very marked.

3.Very penetrating; deep pain.

4. Huge; rampant; excessive; too much.

5.Far-reaching, very important.

5) Tremendous

1. Terrible, unusual, extraordinary

\section{6) Desperate}

1.What despair; makes one despair; despairing

2. Those makes one despair

7) Intense

1. Strong, impetuous.

2.hard, painful.

3.Violente, rude, excessive.

8) Fulminant

1. That strikes down, lightning fires, strike.

2. Haunting.

3. Cruel, terrible, atrocious.

\section{9)Annihilating}

1.Reduces to nothing; nullifies; cancels.

2.destroys; kills; exterminates.

10)Monstrous

1.Huge; extraordinary.

\section{() Chronic pain}

\section{1) Depressing}

1.What depresses; depressing; depressant.

2) Persistent

1.Constant; continuous, persists; insists.

2. What remains; perseveres.

3) Anguishing

1.What anguishes; anguished.

4) Disastrous

1.What is or produces calamitous event, especially that which occurs suddenly, causing great damage or injury.

5) Prejudicial

1.what harms; harmful; damaging.

6) Painful

1.What produces pain; painful; sore.

7) Unbearable

1.not tolerable; intolerable.

2.uncomfortable; hurts.

8) Frightening

1.That frightens; frightening

9) Cruel

1.hard; insensitive; bloody.

10) Uncomfortable

1.Not comfortable; uncomfortable.

Figure 3 - Multidimensional Pain Evaluation Scale (MPES) (Faleiros Sousa et. al.) 


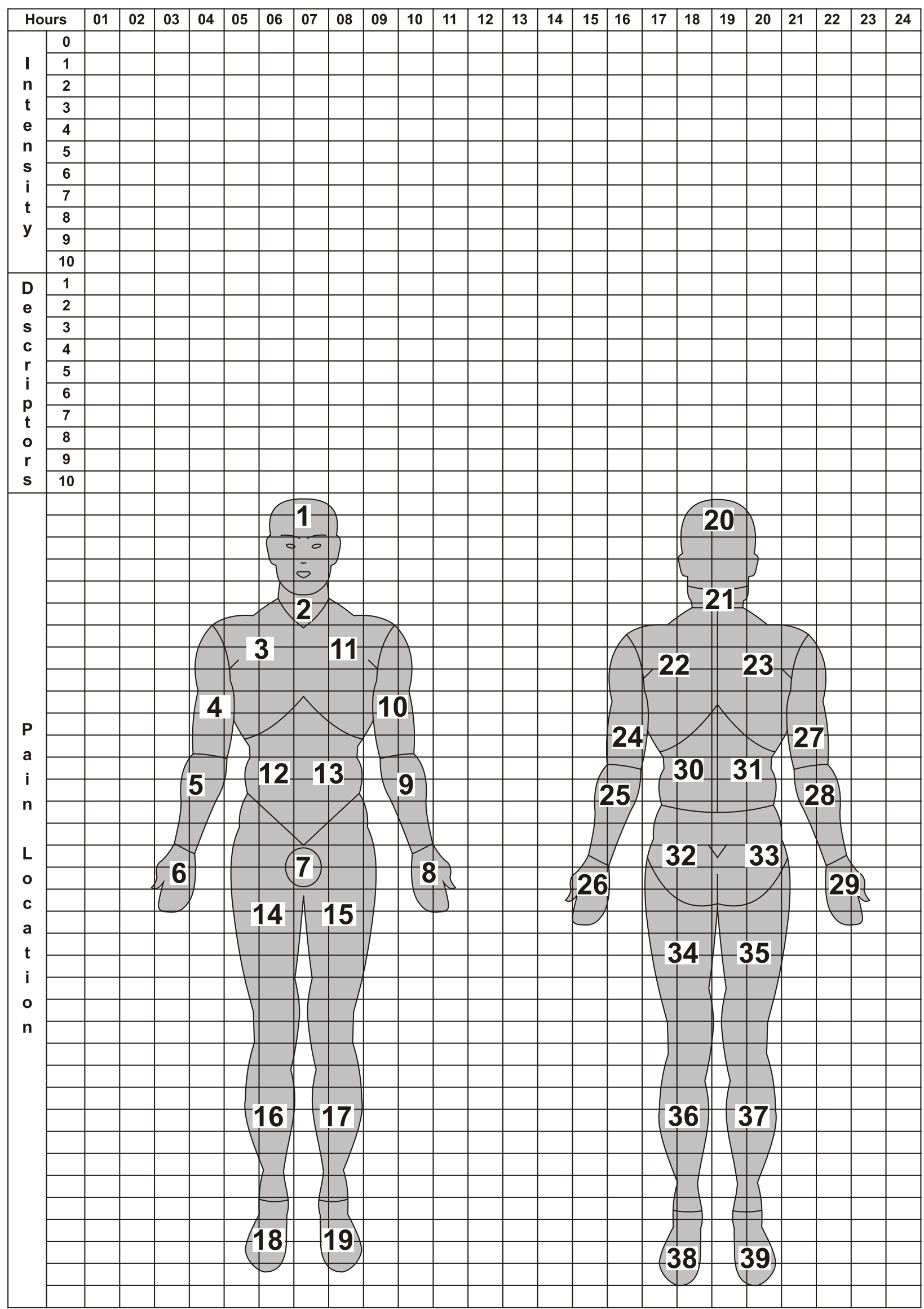

Figure 4 - Multidimensional Pain Evaluation Scale (MPES), Faleiros Sousa et. al. 


\section{Discussion}

The obtained power of 0.99 was very close to 1.0 , such as observed in studies in which such estimates of magnitudes are matched to line-length ${ }^{(13-14)}$. The equivalence between the empirical and the predicted power, when two modalities are used, is an evidence of confirmation of Steven's Power Law ${ }^{(13)}$.

This result indicates that any change in the stimulus would produce similar changes in judgments performed through two modalities. Studies have used line-length, matching them to other modalities such as brightness and loudness and the found prediction was nearly perfect(14-15).

This study resulted in a pain descriptors inventory for the Portuguese language, inserting Brazil into the world scene of human pain evaluation. With this published inventory, we can say that there is a multidimensional scale, and not an only one-dimensional scale, for such purposes.

The instrument of descriptors for the Portuguese language captures indicators that allow analyzing the sensitive, affective and cognitive dimensions. Studies previously published aimed to generate knowledge in the field so that a culture of teaching, research and care would be constructed in the field of human pain evaluation in Brazil ${ }^{(1-2,4-5)}$. The efficiency of treatments and their development, though, depends on the reliable and valid evaluation and measurement of pain, as represented by this study, in laboratory and clinical settings.

\section{Conclusions}

Pain is considered a vital signal (the fifth), as important as any other, which should be always evaluated in a clinical environment in order to implement interventions.

We developed a practical, reliable, sensitive, and valid instrument, and we also advanced from ordinal measurement to quantification in Brazilian pain research, placing us at the forefront of the world scene. These measurements are methodologically sound, present reproducibility and the possibility to follow-up and analyze the mechanisms of action of different drugs and other therapies.

The evaluation and measurement of pain are essential for nursing and useful in all stages of care delivery and production of knowledge, which among other objectives, aim to determine the appropriate metrological characteristics to different types of pain, management and monitoring performed by the nursing team, and is vital for the success of treatment of those who experience pain.

\section{References}

1. Pereira LV, Sousa FAEF. Psychophysical evaluation of the descriptors of pain in the postoperative. Rev Latino-am Enfermagem 2007 junho;15(3):474-9.

2. Pereira LV, Sousa FAEF. Categorization of postoperative pain descriptors in the sensitive, affective and evaluative dimensions of painful experiences. Rev Latino-am Enfermagem 2007 agosto; 15(4):563-7.

3. Melzack R, Torgerson WS. On the language of pain. Anesthesiology 1971; 34(1):50-9.

4. Sousa FAEF, Da Silva JA. Uso e aplicação da metodologia psicofísica na pesquisa em Enfermagem. Rev Latino-am Enfermagem 1996; 4(2):147-78.

5. Sousa FAEF, Hortense P. Social perception of nursing professional assessed by different scales. Rev Latino-am Enfermagem 2006 agosto; 14(6):857-62.

6. Sousa FAEF, Pereira LV, Hortense P. Avaliação e mensuração da percepção da dor. In: Alves O Neto, Costa CMC, Siqueira JTT, Teixeira MJ, et al Dor: Princípios e prática. Porto Alegre (RS): Artmed; 2009. p. 370-81.

7. Melzack R. The McGill pain questionnaire: major properties and scoring methods. Pain 1975; 1:277-99.

8. Ferreira $\mathrm{ABH}$. Novo dicionário Aurélio da língua portuguesa.

$2^{a}$ ed. Rio de Janeiro (RJ): Nova Fronteira; 1986.

9. Hoerr NL, Osol A. Dicionário médico ilustrado: Blakiston. São Paulo (SP): Andrei; 1970.

10. Michaelis H. Dicionário inglês-português. São Paulo (SP): Melhoramentos; 1989.

11. Sant'Ana RPM, Sousa FAEF. Identification and validation of Brazilian Chronic Pain Descriptors. Pain Manag Nurs 2009; 10(2):85-93.

12. Sant 'Ana RPM, Pereira LV, Saltareli S, Faleiros Sousa FAE. Chronic pain descriptors: a Psychophysical study. Fechner Day 2004; 20:512-7.

13. Stevens SS. On predicting exponents for cross-modality matches. Percept Psychophys 1969; 6:385-401.

14. Collins AA, Gescheider GA. The measurement of loudness in individual children and adults by absolute magnitudes estimation and cross-modality matching. J Acoust Soc Am 1989; 85:2012-21. 15. Stevens SS. On the psychopysical law. Psychol Rev 1957; 64(3):153-81.

Received: Dec. $1^{\text {st }} 2008$

Accepted: Oct. $6^{\text {th }} 2009$ 